\title{
Evaluation of antagonistic activities against Pythium myriotylum and plant growth promoting traits of Streptomyces isolated from Cocoyam (Xanthosoma sagittifolium (L.) Schott) rhizosphere
}

\author{
Peguy Flora Djuidje Kouomou ${ }^{1,3}$, Cécile Annie Ewane ${ }^{1,2}$, Sylvain Lerat ${ }^{3}$, Denis Omokolo Ndoumou ${ }^{4}$, Carole \\ Beaulieu $^{3}$, Thaddée Boudjeko ${ }^{1,2}$ \\ ${ }^{1}$ Laboratory of Phytoprotection and Valorization of Plants Resources, Biotechnology Centre-Nkolbisson, P.O. Box 3851, \\ Messa, Yaoundé, Cameroon \\ ${ }^{2}$ Department of Biochemistry, Faculty of Science, University of Yaoundé I, P.O BOX 812, Yaoundé, Cameroon \\ ${ }^{3}$ Centre SEVE, Département de Biologie, Université de Sherbrooke, Sherbrooke, Québec J1K2R1, Canada \\ ${ }^{4}$ Laboratory of Plant Physiology, Higher Teacher's Training College, P.O BOX 812, Yaoundé, Cameroon
}

*Corresponding author: boudjeko@yahoo.com

\begin{abstract}
The focus of this study was to isolate, evaluate and characterize cocoyam rhizospheric actinobacteria collected from Mount Cameroon for their potential antagonistic activities against Pythium myriotylum, the causative agent of cocoyam root rot disease, and/or their ability to promote plant growth. Actinobacteria were isolated from soil samples by using serial dilution method. Dual culture assay was used to screen the isolates against fungal phytopathogens including $P$. myriotylum. The selected isolates were characterized morphologically, physiologically, biochemically and genetically. Furthermore, these isolates were subjected to in vitro production of various plant growth promoting (PGP) traits. Among the 287 isolates distributed into 12 distinct groups, PFK4, PFBOT7 and PFEL2 had high antagonistic effects against $P$. myriotylum and they were regarded as promising candidates for further study of their biocontrol ability. The identification of actinobacterial isolates was done using universal PCR of partial 16S rRNA sequences combined with bioinformatics and phylogenetic procedures. The results revealed that all these isolates belong to the genus Streptomyces spp. The isolate PFK4 showed 99\% similarity with Streptomyces albulus while PFBOT7 showed 99\% similarity with Streptomyces albus and PFEL2 showed $98 \%$ similarity with Streptomyces gandoceansis based on their 16S rRNA gene sequences. In this study for the first time, we report S. gandocaensis strain for the biological control of Pythium myriotylum. The role of these isolates in Plant Growth Promotion (PGP) by in vitro production of PGP traits such as phosphate solubilisation, siderophore, indole-3-acetic acid (IAA), ACC deaminase and cell wall degrading enzymes production were also evaluated and showed as potential PGP agents. Concurrent production of PGP substances coupled with broad spectrum of antifungal and antibacterial activities of these three strains suggest their potential use as promising biocontrol and PGP tools for the development of an alternative control method for cocoyam cultivation.
\end{abstract}

Keywords: Xanthosoma sagittifolium (cocoyam); Streptomyces; Mount Cameroon; Biocontrol trait; Plant growth promotion. Abbreviations: ACC deaminase_1-aminocyclopropane-1-carboxylate deaminase. IAA_indole-3-acetic acid. PGP_Plant Growth Promotion. CRRD_Cocoyam Root Rot Disease. FAO_Food and Agriculture Organisation. PDA_Potato Dextrose Agar. CFU_Colony Forming Unit. ISP_International Streptomyces Project. HCN_Hydrogen Cyanide. GLM medium_Glucose-yeast extract Malt medium.

Introduction

Cocoyam (Xanthosoma sagittifolium (L.) Schott) is an important tuber crop consumed by more than 400 million of people in tropics and subtropics regions in the world (Reyes et al., 2005). The importance of cocoyam mostly relies on its edible tubers and leaves. It is a rich source of carbohydrates, essential amino acids, vitamins and mineral for human diet (Sefa-Dedeh and Agyir-Sackey 2004). Ranked among the six roots and tuber crops worldwide, cocoyam is consumed by millions of people in most tropical zones in Africa, America and Asia and has an annual production of about 10 million tonnes
(FAOSTAT 2014). Despite its importance as a staple food in many countries, Cocoyam Root Rot Disease (CRRD), caused by $P$. myriotylum, is the most devastating disease of cocoyam. It is caused by distinct isolates of $P$. myriotylum capable of specifically infecting cocoyam (Perneel et al., 2006; Boudjeko et al., 2006). In Cameroon, this soil-borne pathogen is responsible for up $90 \%$ loss of yield in some plantation (Nzietchueng 1983) and shifting cultivation practices. When this disease appears in one area, the future plantings have to be moved to another field because $P$. myriotylum in cocoyam is 
difficult to control using classical control methods such as chemicals. Although the root rot disease and the causal pathogen have been well characterized (Boudjeko et al., 2005; Nyochembeng et al., 2007), knowledge of the reliable control measures for CRRD is still poor. Additionally, no resistant cocoyam variety has been developed yet.

Field observations indicate that andosols (FAO soil classification system) of Mount Cameroon area are naturally suppressive to $P$. myriotylum on cocoyam and this suppression was significantly reduced following pasteurisation and treatment with fungicide and bactericide (Adiobo et al., 2007). Furthermore, population density of useful actinomycetes, fluorescent Pseudomonas and Trichoderma spp. were significantly higher after using andosols (Adiobo et al., 2007). In order to elucidate the possible contribution of these microbial groups to Mount Cameroon andosol suppression, fluorescent pseudomonas (Pseudomonas CMR5c and CMR12a) strains antagonistic to $P$. myriotylum were isolated from healthy cocoyam rhizosphere and these strains were identified as novel and promising biocontrol agents of $P$. myriotylum on cocoyam (Perneel et al., 2007; Ma et al., 2016). Otherwise, in vivo pretreatment of cocoyam plants with strains of Trichoderma asperellum (strains PR10 and PR11) isolated from soil samples taken from the rhizosphere of cocoyam plants in Yaounde (Cameroon) could reduce $P$. myriotylum infection by $50 \%$ (Mbarga et al., 2012). Actinomycetes, one of the more numerous microbial groups in suppressive andosols are common inhabitants of plant rhizosphere and plant surfaces (Doumbou et al., 2001; Sadeghi et al., 2017). Their ability to control plant-pathogenic Oomycetes has been widely reported (El-Tarabily et al., 2010; Yang et al., 2014).

Actinobacteria are Gram positive, aerobic and mycelia-forming bacteria, characterized by a genome with a high $\mathrm{G}+\mathrm{C}$ content. Actinobacteria are saprophytic or symbiotic microorganisms widely associated with plants (Palaniyandi et al., 2013; Mouafo Tchinda et al., 2016). Although actinobacteria have been successfully isolated from epigeous plant tissues (Mouafo Tchinda et al., 2016), the rhizosphere represents the main reservoir for the search of such microorganisms (Aouar et al., 2012; Boudjeko et al., 2017). Some actinobacteria are plant growth promoting (PGP) and can promote growth directly by either facilitating resource acquisition (nitrogen, phosphorus and essential minerals), facilitating iron acquisition through siderophore production and/or modulating plant hormone levels (Schrey and Tarkka 2008, Lugtengberg and Kimilova 2009). Streptomyces is the largest genus of actinobacteria, which are well-known for their ability to produce bioactive metabolites and lytic enzymes (Doumbou et al., 2001).

Exploring the cocoyam rhizosphere from the andosols of Mount Cameroon could contribute to the better comprehension of suppressiveness of that particular sol soil and could provide new potential biocontrol agents for diseases management and productivity of cocoyam crops. This paper describes the isolation, identification, evaluation of antagonistic activities and plant growth promoting traits of Streptomyces $\mathrm{sp}$ with potential for biological control of cocoyam root rot disease, for further used for formulation of potential bio fungicides and /or bio fertilizers.

\section{Results}

\section{$p H$, moisture and organic-matter of soil samples}

The properties of the soils are found in Table 1. The $\mathrm{pH}$ of the soil samples ranged from 6.25 to 7.61. The Kumba forest soil was slightly acidic ( $\mathrm{pH}$ 6.25), Ekona Lelu 1 field and Ekona Lelu 2 forest soils were slightly basic, with $\mathrm{pH} 7.61$ and 7.53 respectively; while Ekona fields and Boteva forest were neutral with $\mathrm{pH} 7.43$ and 7.48 respectively. The moisture content of the soils ranged from 15.56 to $25.16 \%$. Ekona Lelu 1 field, Ekona Lelu 2 and Kumba forests had similar moisture contents, but differences were observed with the moisture contents of Boteva forest and Ekona field. The organic-matter of the soils ranged from 5.41 to 7.92. The organic-matter content of Ekona field was significantly different from those of the other localities (Table 1).

\section{Isolation of actinobacteria from cocoyam rhizosphere}

The total actinobacteria from the rhizosphere of cocoyam plants was from $0.00510^{6}$ to $4.310^{6} \mathrm{CFU}^{-1}$ dried soil on Bennett medium and $3.210^{6}$ to $7.810^{6} \mathrm{CFU} . \mathrm{g}^{-1}$ dried soil on GLM medium (Table 1). 287 actinobacteria were isolated from soil samples by dilution spread on GLM agar. Based on their morphological characteristics and frequency in different localities, these 287 actinobacterial isolates obtained were distributed into 12 groups of isolates (PEKO-1, PEKO-2, PEL1-1, PEL1-2, PFK1, PFK2, PFK4, PFBOT1, PFBOT2, PFBOT4, PFBOT7 and PFEL2) (Table 2). The 12 isolates were divided into 2 groups according to their growth rate. The colonies of PEKO-1, PEL1-1, PFK4 and PFBOT7 were observed after 2 to 3 days of incubation and were; therefore, the fast growing isolates. 67 (about 23\%) isolates were assigned to group PFK4, which was characterized by spiral spore chains, and as grey-white, brownwhite, green and white aerial mycelium on ISP2, ISP3, ISP4 and ISP5 media. 58 (about 20\%) isolates were assigned to group PFBOT7, which was characterized by spiral spore chains, beige aerial mycelium on ISP2, ISP3, ISP4 and ISP5 media, and also orange and yellow substrate mycelium on ISP2, ISP3, ISP4 and ISP5 media. PEL1-2 group (14 isolates, about $54 \%$ ) was characterized by rectiflexible spores. PFBOT4 group ( 8 isolates, about $2 \%$ ) and PFBOT7 group (58 isolates, about 20\%) had isolates that did not produce diffusible pigments on ISP7 medium. PFK1 group (8 isolates, about 2\%), PFBOT2 (3 isolates, about $1 \%$ ) and PFBOT4 ( 8 isolates, about $2 \%$ ) displayed isolates specific to the forest (Table 2). In addition, the twelve isolates had different colours of aerial and substrate mycelium on ISP media (Table 3). Of the 12 isolates, only PEL1-2 was able to produce melanin pigment on ISP6 medium. Diffusible pigments were produced by isolates PEKO-1, PEKO-2, PEL1-1, PEL1-2, PFK1, PFK2, PFK4, PFBOT1, PFBOT2 and PFEL2 on ISP7 medium (Table 3).

\section{Antimicrobial activity of actinobacterial isolates}

The antifungal activity of the 12 distinct isolates determined by dual culture on PDA revealed that all the 12 isolates (100\%) showed antifungal activity (Fig 1). Isolates PFK4, PFBOT7 and 
Table 1. Soil properties (pH, moisture, organic matter) and number of colony forming units (c.f.u) per gram of dried soil sample.

\begin{tabular}{|c|c|c|c|c|c|c|}
\hline Location & Geographical coordinates & $\mathrm{pH}$ & Moisture content (\%) & Organic-matter content $(\%)$ & $\begin{array}{l}10^{6} \text { c.f.u. }{ }^{-1} \text { dried soil } \\
\text { GLM }\end{array}$ & Bennett \\
\hline Bonakanda & $\left(04^{\circ} 12^{\prime} 417^{\prime \prime N}, 009^{\circ} 16^{\prime} 303^{\prime \prime} \mathrm{E}\right)$ & $7.57 \pm 0.01$ & $21.2 \pm 0.58$ & $7.13 \pm 0.43$ & uncountable & uncountable \\
\hline Boteva & $\left(04^{\circ} 13^{\prime} 159^{\prime \prime N}, 009^{\circ} 17^{\prime} 132^{\prime \prime} \mathrm{E}\right)$ & $7.48 \pm 0.09 a$ & $15.56 \pm 0.93 b$ & $7.92 \pm 0.06 a$ & 7.8 & 4.3 \\
\hline Ekona & $\left(04^{\circ} 12^{\prime} 837^{\prime \prime N}, 009^{\circ} 19^{\prime} 828^{\prime \prime} \mathrm{E}\right)$ & $7.43 \pm 0.05 a$ & $17.50 \pm 0.78 b$ & $5.41 \pm 0.20 c$ & 3.2 & uncountable \\
\hline Ekona Lelu 1 & $\left(04^{\circ} 16^{\prime} 413^{\prime \prime N}, 009^{\circ} 18^{\prime} 062^{\prime \prime} \mathrm{E}\right)$ & $7.61 \pm 0.05 a$ & $25.16 \pm 0.92 a$ & $6.75 \pm 0.26 b$ & 4.6 & uncountable \\
\hline Ekona Lelu 2 & $\left(04^{\circ} 16^{\prime} 110^{\prime \prime N}, 009^{\circ} 18^{\prime} 433^{\prime \prime} \mathrm{E}\right)$ & $7.53 \pm 0.08 a$ & $21.33 \pm 0.29 a$ & $7.12 \pm 0.10 b$ & 4.8 & 2.8 \\
\hline Kumba & $\left(04^{\circ} 30^{\prime} 716^{\prime \prime N}, 009^{\circ} 18^{\prime} 433^{\prime \prime} \mathrm{N}\right)$ & $6.25 \pm 0.2 b$ & $19.76 \pm 1.08 a b$ & $7.65 \pm 0.10 a$ & 7.3 & 0.005 \\
\hline
\end{tabular}
grew well and sporulated abundantly on the medium.
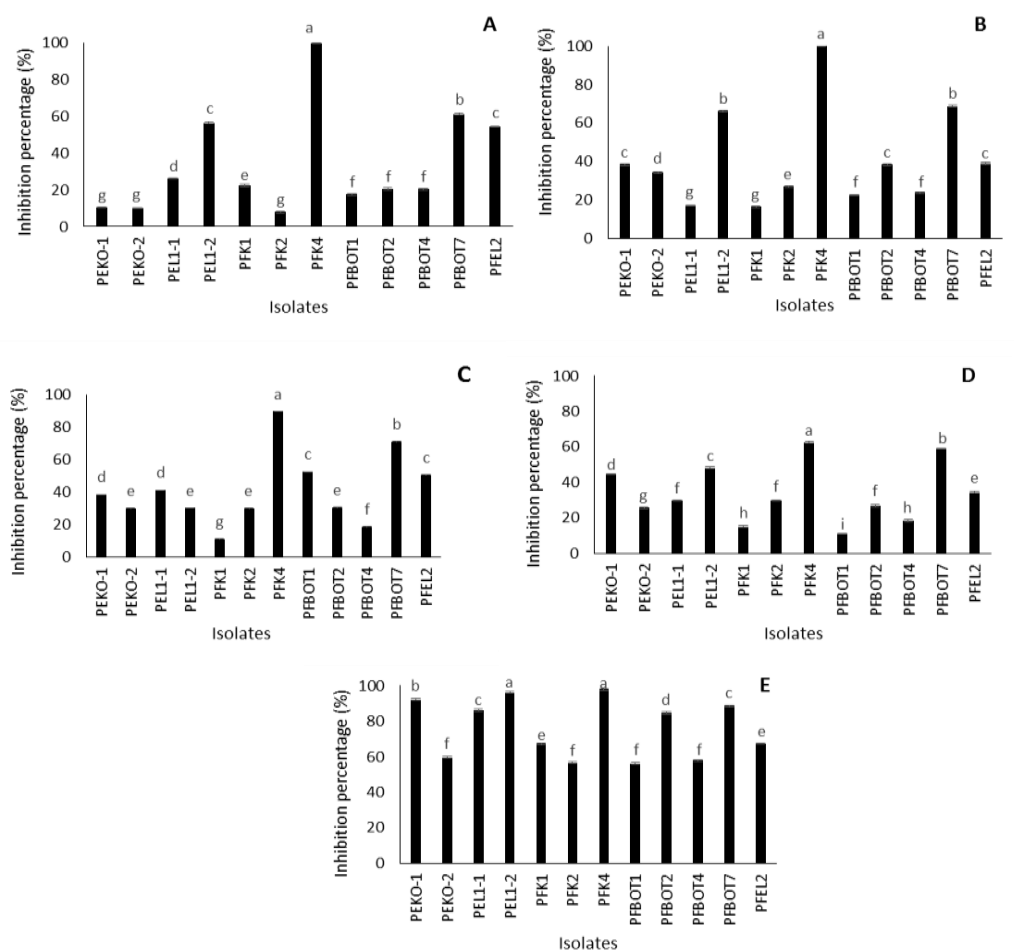

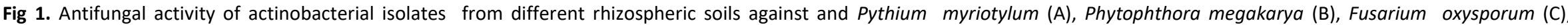

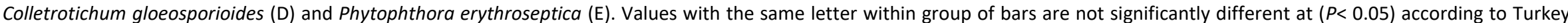
test. 
Table 2. Number and frequency of actinobacterial isolates from cocoyam rhizosphere at Ekona (Eko), Ekona Lelu 1 (EL1), Ekona Lelu 2 (EL2), Kumba (Kum) and Boteva (Bot).

\begin{tabular}{llll}
\hline Isolates & Site samples & Number of similar isolates & Frequency (\%) \\
\hline PEKO-1 & Eko, EL1, EL2 & 27 & 9.41 \\
PEKO-2 & Eko, EL1 & 5 & 1.74 \\
PEL1-1 & EL1, EL2 & 22 & 7.66 \\
PEL1-2 & EL1, EL2 & 14 & 4.87 \\
PFK1 & Kum & 8 & 2.79 \\
PFK2 & Kum, EL2 & 12 & 4.18 \\
PFK4 & Kum, Bot, Eko & 67 & 23.34 \\
PFBOT1 & Bot, Eko, EL1 & 32 & 11.15 \\
PFBOT2 & Bot & 3 & 1.05 \\
PFBOT4 & Bot & 8 & 2.79 \\
PFBOT7 & Bot, Eko, EL1, Kum & 58 & 20.21 \\
PFEL2 & EL2, Kum, EL1 & 31 & 10.80 \\
\hline were presented at least in two localities excepted PFK1, PFBOT2 and PFBOT4. Whenever, isolate PFK4 was mostly represented with 23.34\% of frequency follow by PFBOT7 with 20.21\%.
\end{tabular}

Most isolates were presented at least in two localities excepted PFK1, PFBOT2 and PFBOT4. Whenever, isolate PFK4 was mostly represented with $23.34 \%$ of frequency follow by PFBOT7 with $20.21 \%$.
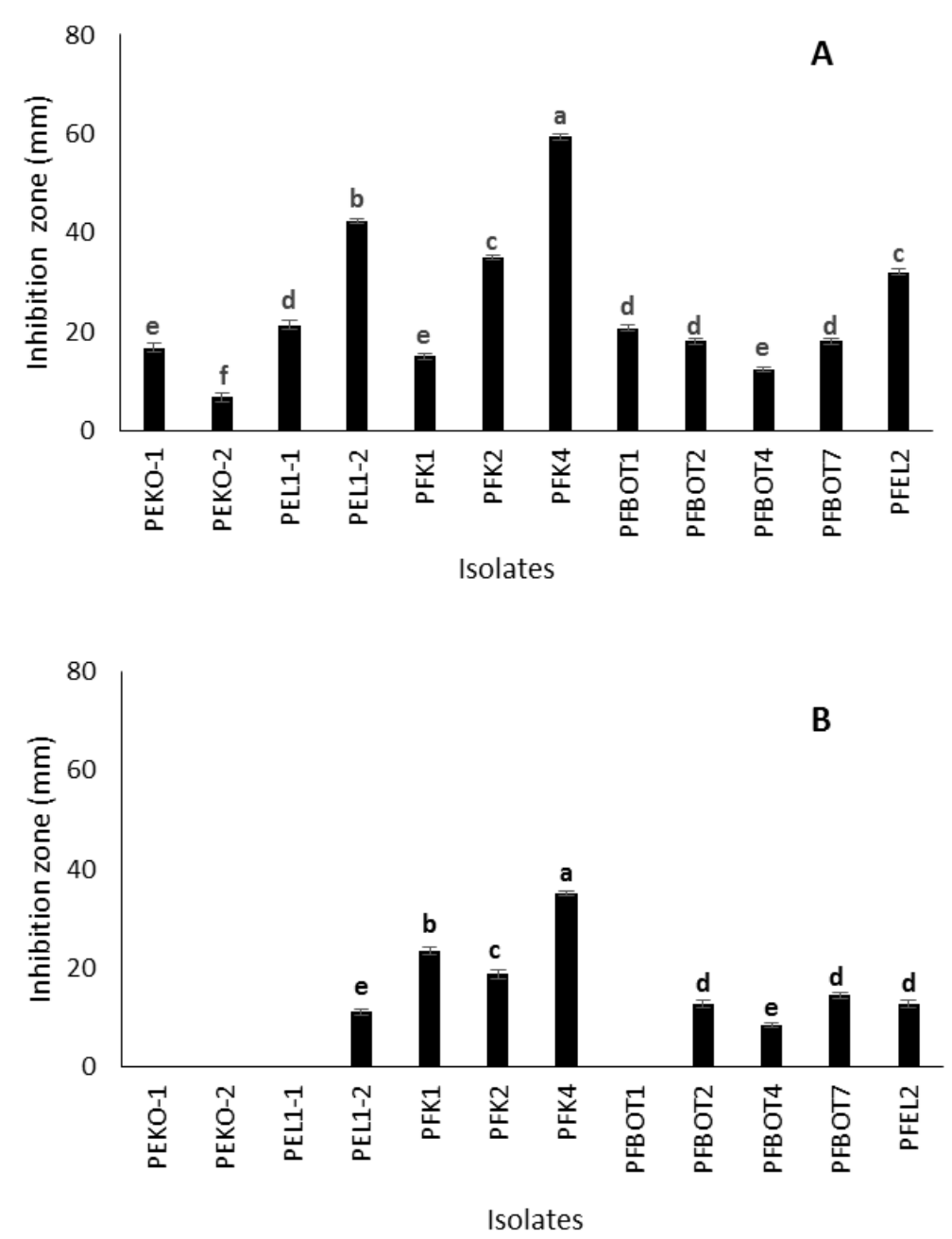

Fig 2. Antibacterial activity of actinobacterial isolates towards Agrobacterium tumefaciens (A) and Streptomyces scabiei EF-35 (B). Values with the same letter within group of bars are not significantly different at $(P<0.05)$ according to Turkey test. 
Table 3. Morpho-cultural characteristics of actinobacterial isolates grown on different media.

\begin{tabular}{|c|c|c|c|c|c|}
\hline $\mathrm{n}$ & Isolates & Aerial mycelium & Substrate mycelium & Pigment production & $\begin{array}{l}\text { Chain spore } \\
\text { arrangement }\end{array}$ \\
\hline 1 & PEKO-1 & $\begin{array}{l}\text { Brown aerial mycelium on ISP2, ISP3, ISP4 } \\
\text { and ISP5 media. }\end{array}$ & $\begin{array}{l}\text { Brown-light, uncoloured, dark brown } \\
\text { and white substrate mycelia on ISP2, } \\
\text { ISP3, ISP4 and ISP5 media. }\end{array}$ & $\begin{array}{l}\text { Diffusible pigment on } \\
\text { ISP7. }\end{array}$ & Spiral \\
\hline 2 & PEKO-2 & $\begin{array}{l}\text { Green-white, green, brown and grey aerial } \\
\text { mycelia on ISP2, ISP3, ISP4 and ISP5 media. }\end{array}$ & $\begin{array}{l}\text { Grey-dark, uncoloured, green, white } \\
\text { substrate mycelia on ISP2, ISP3, ISP4 } \\
\text { and ISP5 media. }\end{array}$ & $\begin{array}{l}\text { Diffusible pigment on } \\
\text { ISP7 }\end{array}$ & Spiral \\
\hline 3 & PEL1-1 & $\begin{array}{l}\text { Brown chocolate, brown-white aerial mycelia } \\
\text { on ISP2, ISP3, ISP4 and ISP5 media. }\end{array}$ & $\begin{array}{l}\text { Dark grey substrate mycelium on ISP2, } \\
\text { ISP3, ISP4 and ISP5 media. }\end{array}$ & $\begin{array}{l}\text { Diffusible pigment on } \\
\text { ISP7. }\end{array}$ & Spiral \\
\hline 4 & PEL1-2 & $\begin{array}{l}\text { Brown-yellowish, brown, grey, and grey- } \\
\text { white aerial mycelia on ISP2, ISP3, ISP4 and } \\
\text { ISP5 media. }\end{array}$ & $\begin{array}{l}\text { Yellow, orange, uncoloured, grey } \\
\text { substrate mycelia on ISP2, ISP3, ISP4 } \\
\text { and ISP5 media. }\end{array}$ & $\begin{array}{l}\text { Melanin and } \\
\text { diffusible pigments } \\
\text { on ISP6 and ISP7. }\end{array}$ & Rectiflexible \\
\hline 5 & PFK1 & $\begin{array}{l}\text { Grey, brown, grey-white and white aerial } \\
\text { mycelia on ISP2, ISP3, ISP4 and ISP5 media. }\end{array}$ & $\begin{array}{l}\text { Brown, dark brown and white } \\
\text { substrate mycelia on ISP2, ISP3, ISP4 } \\
\text { and ISP5 media. }\end{array}$ & $\begin{array}{l}\text { Diffusive pigment on } \\
\text { ISP7. }\end{array}$ & Spiral \\
\hline 6 & PFK2 & $\begin{array}{l}\text { Green-yellowish, brown and yellow aerial } \\
\text { mycelia on ISP2, ISP3, ISP4 and ISP5 media. }\end{array}$ & $\begin{array}{l}\text { Orange, yellow, and yellow substrate } \\
\text { mycelium on ISP2, ISP3, ISP4 and ISP5 } \\
\text { media. }\end{array}$ & $\begin{array}{l}\text { Diffusible pigment on } \\
\text { ISP7. }\end{array}$ & Spiral \\
\hline 7 & PFK4 & $\begin{array}{l}\text { Grey-white, grey-greenish, grey and white } \\
\text { aerial mycelia on ISP2, ISP3, ISP4 and ISP5 } \\
\text { media. }\end{array}$ & $\begin{array}{l}\text { Yellow and white substrate mycelia on } \\
\text { ISP2, ISP3, ISP4 and ISP5 media. }\end{array}$ & $\begin{array}{l}\text { Diffusive pigment on } \\
\text { ISP7. }\end{array}$ & Spiral \\
\hline 8 & PFBOT1 & $\begin{array}{l}\text { Dark brown-dark, light brown aerial mycelia } \\
\text { on ISP2, ISP3, ISP4 and ISP5 media. }\end{array}$ & $\begin{array}{l}\text { Orange, yellow substrate mycelia on } \\
\text { ISP2, ISP3, ISP4 and ISP5 media. }\end{array}$ & $\begin{array}{l}\text { Diffusive pigment on } \\
\text { ISP7. }\end{array}$ & Spiral \\
\hline 9 & PFBOT2 & $\begin{array}{l}\text { Green, greenish, grey and green aerial } \\
\text { mycelia on ISP2, ISP3, ISP4 and ISP5 media. }\end{array}$ & $\begin{array}{l}\text { Uncoloured, green-dark and dark } \\
\text { brown substrate mycelia on ISP2, ISP3, } \\
\text { ISP4 and ISP5 media. }\end{array}$ & $\begin{array}{l}\text { Diffusible pigment on } \\
\text { ISP7. }\end{array}$ & Spiral \\
\hline 10 & PFBOT4 & $\begin{array}{l}\text { Grey-yellowish, grey and yellow aerial } \\
\text { mycelia on ISP2, ISP3, ISP4 and ISP5 media. }\end{array}$ & $\begin{array}{l}\text { Yellow and uncoloured substrate } \\
\text { mycelia on YMEA, ISP3, ISP4 and ISP5 } \\
\text { media. }\end{array}$ & None & Spiral \\
\hline 11 & PFBOT7 & $\begin{array}{l}\text { Beige, Dark beige, light beige and light beige } \\
\text { aerial mycelia on ISP2, ISP3, ISP4 and ISP5 } \\
\text { media. }\end{array}$ & $\begin{array}{l}\text { Orange, cream and uncoloured } \\
\text { substrate mycelia on ISP2, ISP3, ISP4 } \\
\text { and ISP5 media. }\end{array}$ & None & Spiral \\
\hline 12 & PFEL2 & $\begin{array}{l}\text { Yellow-greenish, greenish, green-white and } \\
\text { light beige aerial mycelia on YMEA, ISP3, ISP4 } \\
\text { and ISP5 media. }\end{array}$ & $\begin{array}{l}\text { Yellow, Dark brown, brown and } \\
\text { uncoloured substrate mycelia on ISP2, } \\
\text { ISP3, ISP4 and ISP5 media. }\end{array}$ & $\begin{array}{l}\text { Diffusible pigment on } \\
\text { ISP7. }\end{array}$ & Spiral \\
\hline
\end{tabular}

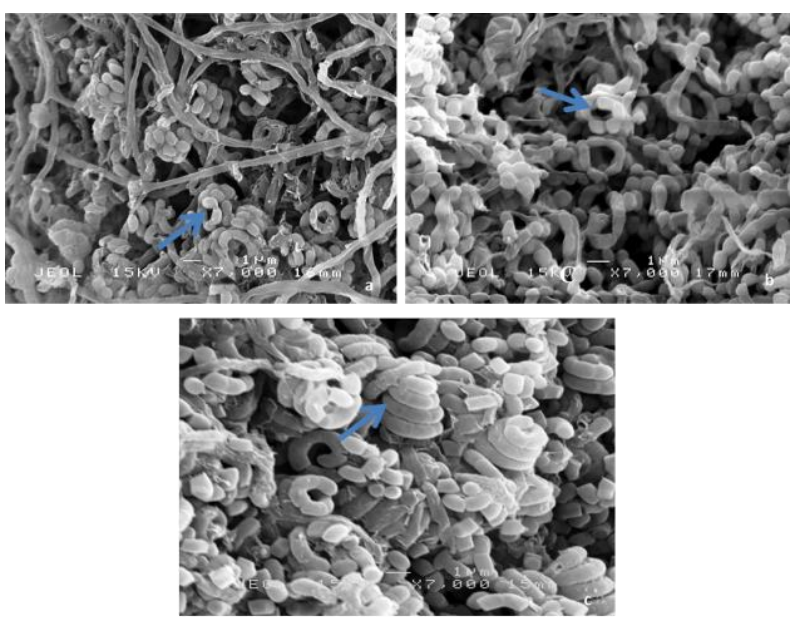

Fig 3. Scanning electron microscopy (SEM) of selected actinobacterial isolates isolated from cocoyam rhizosphere in south-west localities in Cameroon showing spiral spore chain morphology (Arrow), x 7.000.(A) PFK4 (B) PFBOT7, (C) PFEL2. All selected isolates presented smooth arrangement of spore chains 
Table 4. Extracellular enzymes activities and plant growth-promoting properties of antagonistic actinobacterial isolates from cocoyam rhizosphere

\begin{tabular}{lccc}
\hline Proprieties & PFK4 & PFBOT7 & PFEL2 \\
\hline Lytic enzymes production & & ++ & +++ \\
\hline Protease & +++ & ++ & ++ \\
Chitinase & ++ & +++ & +++ \\
Lipase & ++++ & + & - \\
Cellulase & - & + & - \\
Pectinase & + & & + \\
Plant growth promoting traits & & & + \\
Phosphate solubilization & + & +++ & ++ \\
Siderophore & +++ & +++ & + \\
ACC deaminase & ++ & ++ & - \\
HCN production & +++ & + & +
\end{tabular}

Protease, chitinase, lipase, cellulase and pectinase production; phosphate solubilization, siderophore were recorded as follows: -: no growth; +: halo zone of 1-20 mm; ++: halo zone of 21-40 mm; +++: halo zone of 41-60 mm; ++++, halo zone of 61-80 mm and above. Phosphate solubilization, Siderophore and ACc deaminase were recorded as follows: (-) no growth; (+) little growth; (++) medium growth, (+++) good growth. For HCN production, the following rating scale was used: $-=$ no color change, $+=$ light reddish brown, $++=$ medium reddish brown, $+++=$ dark reddish brown.
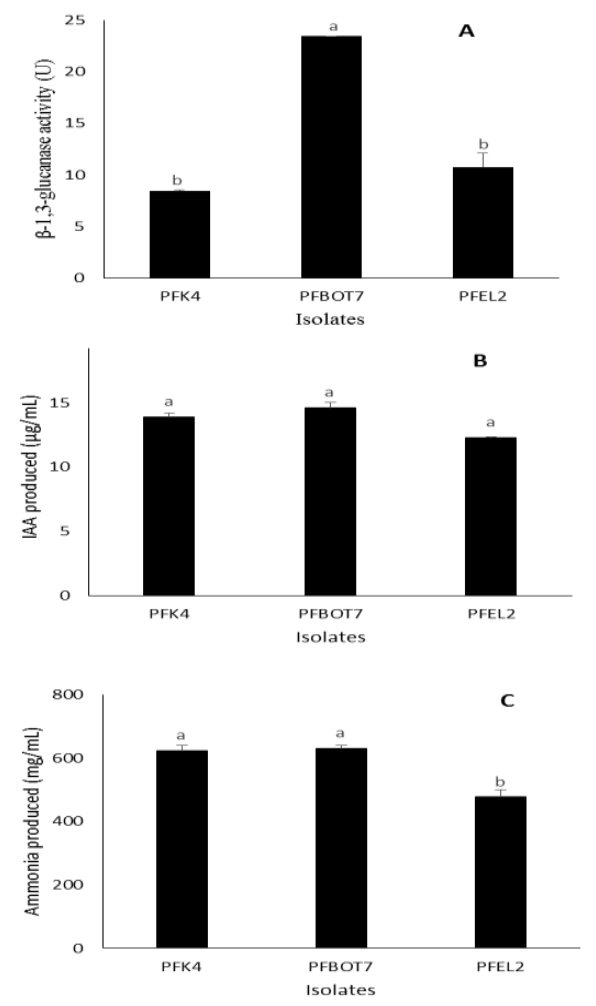

Fig 4. Quantitative evaluation of biocontrol and plant growth-promoting traits. (A): $\beta-1,3-$ glucanase activity of antagonistic actinobacterial isolates; (B): Auxin production by actinobacterial isolates from cocoyam rhizosphere; all the isolates were grown in the presence of L-tryptophan (0.2\%), and auxin production was measured after 7 days. (C) Ammomia production by antagonistic actinobacterial isolates. Data are averages of three independent replicates. Values with the same letter within group of bars are not significantly different at $(P<0.05)$ according to Turkey test. 
Table 5. Morphological, physiological and biochemical characteristics of three antagonistic actinobacterial isolates.

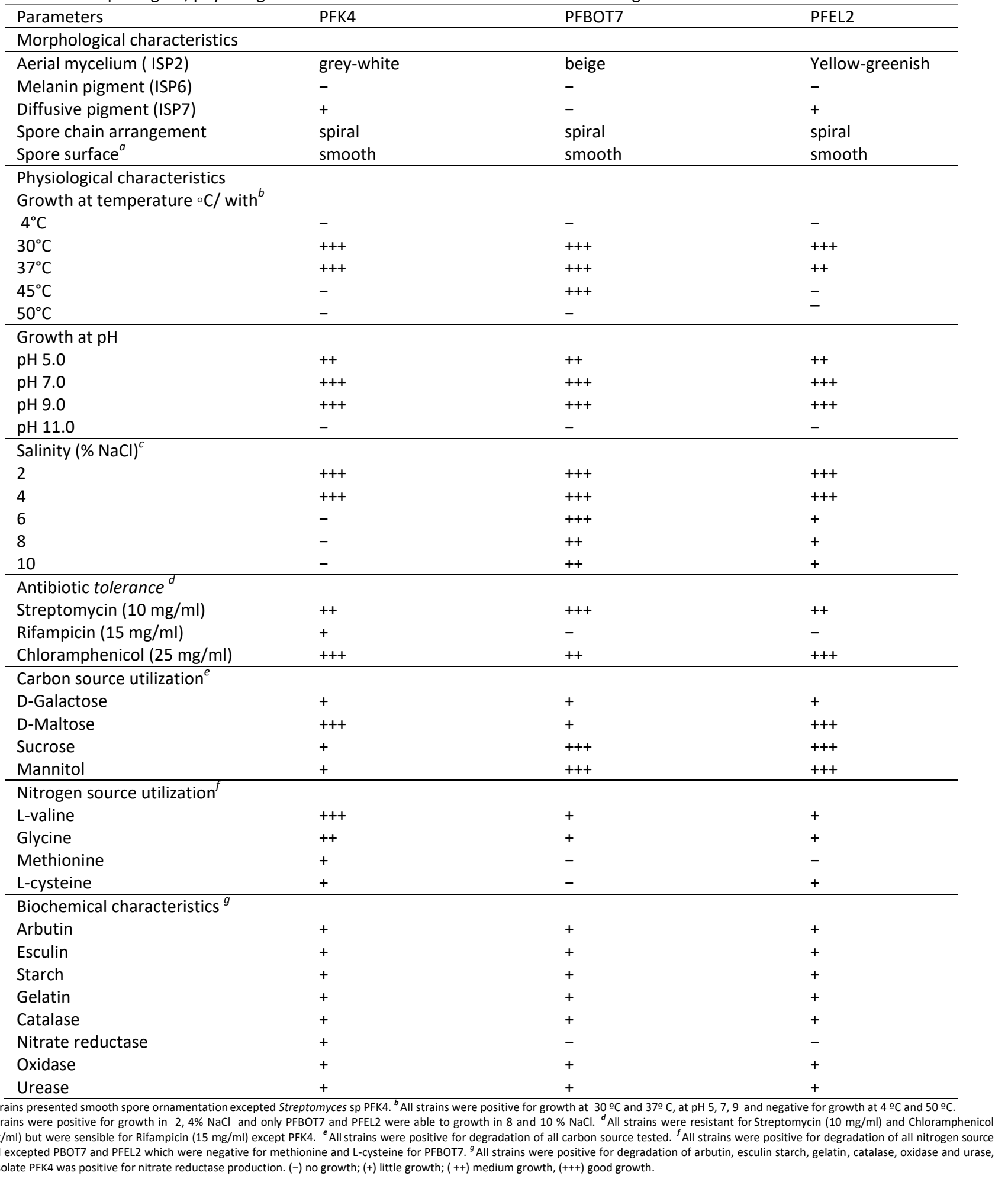




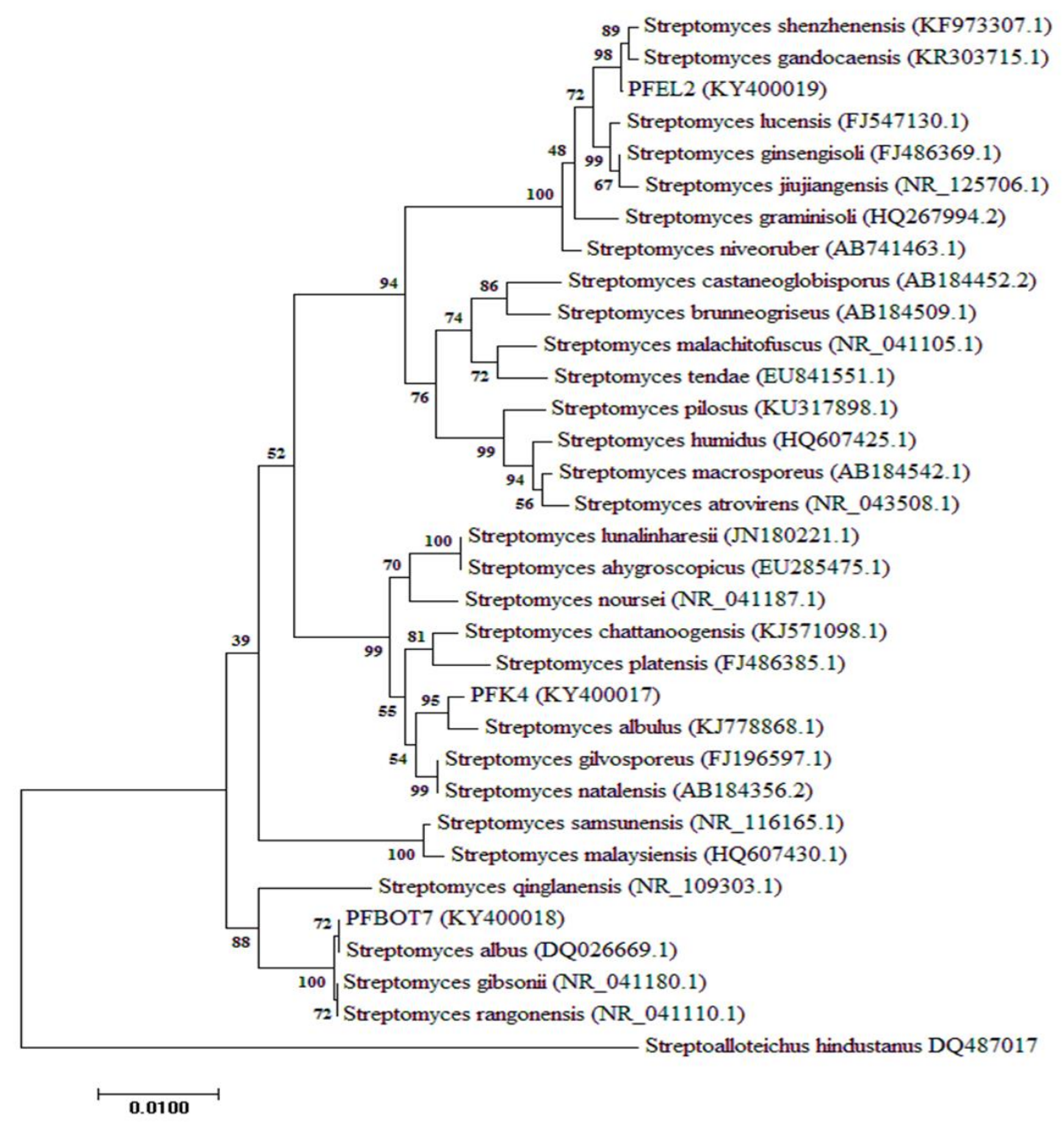

Fig 5. Phylogenetic tree of selected isolates, PFK4, PFBOT7, PFEL2 and the closest Streptomyces species showing phylogenetic relationships based on partial 16S rRNA sequences using neighbor-joining method. Bootstrap percentages based on 1000 resampling are listed at nodes. Bar 0.0100 substitutions per nucleotide position.

PFEL2 showed more than $50 \%$ of inhibition against $P$. myriotylum (Fig 1A). These three isolates also showed antifungal activities against $P$. megakarya. The percentage of growth inhibition was found to be about $100 \%, 69 \%$ and $39 \%$ for PFK4, PFBOT7 and PFEL2, respectively (Fig 1B). On the other hand, the percentage of growth inhibition was found to be about $89 \%, 71 \%$ and $50 \%$ for PFK4, PFBOT7 and PFEL2 in the case of $F$. oxysporum (Fig $1 C$ ). These three isolates were also found to exhibit antifungal activity against $C$. gloeosporioides. The percentage of growth inhibition was found to be about $63 \%, 59 \%$ and $34 \%$ for PFK4, PFBOT7 and PFEL2 respectively (Fig 1D). As shown in Fig 1E, isolates PFK4, PFBOT7 and PFEL2 showed the highest percentage of growth inhibition, of about 98\%, $88 \%$ and $67 \%$ against $P$. erythroseptica.

All the 12 groups of actinobacterial isolates showed antagonistic activity against $A$. tumefaciens. The inhibition zone ranged from $15 \mathrm{~mm}$ to $59 \mathrm{~mm}$. Isolate PFK4 showed the highest inhibition zone $(59 \mathrm{~mm})$, followed by PEL1-2 $(42 \mathrm{~mm})$, PFK2 $(35 \mathrm{~mm})$ and PFEL2 $(32 \mathrm{~mm})$. The lowest inhibition zone was observed by isolate PEKO-2 (about $7 \mathrm{~mm}$ ) (Fig 2A). In the case of S. scabiei EF-35, most (8 out of 12) isolates showed inhibition zones, which were ranged from $8 \mathrm{~mm}$ to $35 \mathrm{~mm}$. The highest inhibition zones were shown by isolate PFK4 $(35 \mathrm{~mm})$, followed by PFK1 $(23 \mathrm{~mm}),($ PFK2 $19 \mathrm{~mm})$ and PFEL2 (13 mm) (Fig 2B). The three isolates which previously showed high antagonistic activities against $P$. myriotylum, $P$. megakarya, $F$. oxysporum, C. gloeospioides and $P$. erythroseptica also showed antibacterial activity against $A$. tumefaciens and Streptomyces scabiei, the two bacteria tested. Isolate PFK4 showed the highest inhibition zone against the two bacteria tested. Three isolates, PFK4, PFBOT7 and PFEL2, were considered as active isolates due to their stronger antagonistic activities (more that $50 \%$ of inhibition) against $P$. myriotylum, the causal agent of cocoyam root rot disease and other fungi and bacterial pathogens. 


\section{Morphological, microscopic, physiological and biochemical characters of selected isolates}

The selected isolates (PFK4, PFBOT7 and PFEI2) showed good growth on ISP2 and ISP4 media and produced different colours of aerial and substrate mycelium on ISP media. None isolate were able to produced melanin pigment on ISP6 medium. Of the selected isolates, PFK4 and PFEL2 produced diffusive pigment on ISP7 medium. The electron microscopy scan images of the three isolates showed aerial mycelia with spiral spores chains. All selected isolates presented smooth arrangement of spore chains (Fig 3).

The selected isolates showed good growth at temperature between $25^{\circ} \mathrm{C}$ and $37^{\circ} \mathrm{C}$, whereas none of them grew at $4{ }^{\circ} \mathrm{C}$ and $50{ }^{\circ} \mathrm{C}$. Only isolates, PFBOT7 and PFEL2 were able to growth at $45{ }^{\circ} \mathrm{C}$. The actinobacterial isolates grown under a gradient of $\mathrm{pH}(5-11)$ indicated that all the isolates grew at the different $\mathrm{pH}$ tested with an optimum growth at $\mathrm{pH} 7.0$ and 9.0. However, isolates PFK4 and PFBOT7 at pH 5.0 showed a good growth. Isolates PFK4, PFBOT7 and PFEL2 showed a very good growth at $\mathrm{pH}$ 9.0. But none of these isolates were able to growth at $\mathrm{pH} 11$. The actinobacterial isolates were able to grow up to $10 \%$. $\mathrm{NaCl}$ concentrations of 6,8 and $10 \%$ was discriminatory for the isolate PFK4. However, isolates PFBOT7 and PFEL2 showed good grown for all $\mathrm{NaCl}$ concentrations tested. All the actinobacterial isolates, were found resistant to antibiotics penicillin (10 $\mathrm{mg} / \mathrm{L})$; chloramphenicol $(25 \mathrm{mg} / \mathrm{L})$, streptomycin sulphate $(10 \mathrm{mg} / \mathrm{L})$, erythromycin $(10 \mathrm{mg} / \mathrm{L})$ (except PFEL2). Only isolate PFK4 was found resistant to antibiotic rifampicin $(15 \mathrm{mg} / \mathrm{L})$. A part of the results of biochemical reaction of the test selected isolates through conventional method; all the isolates were found to be positive to catalase, oxidase, nitrate reductase, urease activities, gelatin liquefaction, starch, casein, arbutin and aesculin degradation. The summary of morphological, physiological and biochemical characters of the antagonistic selected isolates are represented in Table 5.

\section{Extracellular enzyme activities}

Production of extracellular enzymes by microorganisms plays an important role in the management of plant pathogens as well as holds enormous economic potential. In view of extracellular enzymes all the 3 isolates selected from the antimicrobial screening were tested for their extracellular enzyme production like protease, chitinase, lipase, cellulase, pectinase and $\beta-1,3$-glucanase activity. The selected actinobacterial isolates PFK4, PFBOT7 and PFEL2 were positive for protease as shown by clearing zone around colonies. All isolates were positive for chitinase production and formed clear halo zone around the colonies. Chitin degrading activity was found to be high in isolates PFK4 and PFEL2 which exhibited a colloidal chitin degradation zone of 39 and $34 \mathrm{~mm}$, respectively (Table 4). These selected isolates were also positive for lipase production. Lipid degrading activity was found to be high in isolates PFBOT7 and PFEL2, which exhibited a tween 80 degradation zone of 53 and $43 \mathrm{~mm}$, respectively. Out of 3 isolates, only PFBOT7 exhibited cellulase activity. All the 3 isolates produced pectinase except PFEL2 (Table 4). All selected isolates showed positive $\beta-1$, 3-glucanase activity. Isolate PFBOT7 showed the maximum $\beta$-1, 3-glucanase (23.49 $\mathrm{U})$ when compared to other actinobacterial isolates (Fig 4A).

\section{Plant growth-promoting traits of antagonistic isolates}

All the selected isolates were able to solubilize inorganic phosphate and were identified as potential phosphate solubilizing isolates based on a clear halo zone around the colony on Pikovskaya's medium. Siderophore production was detected in all antagonistic actinobacterial isolates on CAS agar medium forming orange halo zone around colonies (Table 4). All the selected isolates were also positive for IAA production. Quantitative range of IAA production was found from 12.28 to $14.61 \mu \mathrm{g} \cdot \mathrm{ml}^{-1}$ (Fig 4B). Isolate Streptomyces sp. PFBOT7 and Streptomyces sp. PFK4 produce the most IAA, with $14.61 \mu \mathrm{g} . \mathrm{ml}^{-}$ ${ }^{1}$ and $13.89 \mu \mathrm{g} \cdot \mathrm{ml}^{-1}$, respectively. All the selected isolates were positive also for the production of ammonia at levels ranging from 477.66 to 630.90 mg.ml ${ }^{-1}$ (Fig. 4C). Isolates Streptomyces sp. PFBOT7 and Streptomyces sp. PFK4 produced the highest amount of ammonia with $631 \mathrm{mg} \cdot \mathrm{ml}^{-1}$ and $624 \mathrm{mg} \cdot \mathrm{ml}^{-1}$, respectively.

Among the 3 selected isolates, 2 isolates (Streptomyces sp. PFK4 and Streptomyces sp. PFBOT7) were positive for $\mathrm{HCN}$ production. Isolate Streptomyces sp. PFK4 exhibited the highest amount of $\mathrm{HCN}$ production as indicated by a dark brown color on the filter paper. All the selected antagonistic isolates were positive for ACC deaminase production by good growing on DF salts minimal agar medium supplemented with ACC. Isolates Streptomyces sp. PFBOT7 and Streptomyces sp. PFEL2 were positive for nitrogen fixation by showing good growth on Jensen medium, which is very poor in nitrogen (Table 4).

\section{Molecular identification}

In order to determine the identity of the antagonistic potential isolates, their $16 \mathrm{~S}$ rDNA were sequenced and analyzed. Partial 16S rRNA nucleotide sequences (1425, 1428 and 1419 nucleotides) of PFK4, PFBOT7 and PFEL2, respectively, were submitted to Gen-Bank and NCBI and accession numbers were obtained as follows: PFK4: KY400017, PFBOT7: KY400018 and PFEL2: KY400019. The phylogenetic and genomic data indicated that all antagonistic isolates based on neighborjoining method matched with Streptomyces sp. genus (Fig 5). The strains were referred to as Streptomyces sp. PFK4; Streptomyces sp. PFBOT7 and Streptomyces sp. PFEL2. Using 16S rRNA gene sequence, the isolate PFK4 showed 99\% similarity with Streptomyces albulus (KJ778868.1); PFBOT7 showed 99\% with Streptomyces albus (DQ026669.1) and PFEL2 showed 98\% with Streptomyces gandoceansis (KR303715.1).

\section{Discussion}

The focus of this study was to isolate, evaluate and characterize cocoyam rhizospheric actinobacteria collected from cocoyam rhizosphere from Bonakanda, Boteva, Ekona, Ekona Lelu 1, Ekona Lelu 2 and Kumba localities of South-West 
region in Cameroon for their potential antagonistic activities against $P$. myriotylum, the causative agent of cocoyam root rot disease, and/or their ability to promote plant growth. In these localities, cocoyam are continuously grown for long time without root rot disease if the plot is not pre-infected. In the present study, actinobacterial isolates were more abundant in Kumba and Boteva soils, which have a high organic-matter and low moisture contents, slightly acidic and neutral $\mathrm{pH}$, respectively. These findings could be attributed to the fact that the content of mineral nutrients such as $\mathrm{Ca}, \mathrm{K}, \mathrm{Mg}$ and $\mathrm{N}$ was higher in andosols from Mount Cameroon region. Soil organic matter content influences soil functions such as moisture retention, infiltration and nutrient retention and release, which may affect density of soil microbial populations. Through enrichment technique and selective media, a total of 287 strains were isolated from the rhizosphere on GLM medium and distributed into 12 distinct groups of isolates based on their morphological characters. All of 12 isolates (100\%) representatives of each group were active against the fungal phytopathogens tested. This percentage was higher than those reported by many authors studying the activity of soil actinomycetes (Aouar et al., 2012; Palaniyandi et al., 2013). Out of 12 distinct rhizospheric actinobacterial isolates, 3 of them namely PFK4, PFBOT7 and PFEL2 exhibited high antagonistic efficiency against $P$. myriotylum and other fungi and bacteria pathogens tested. About $54 \%$ of isolates of andosols of Mount Cameroon were assigned to groups PFK4, PFBOT7 and PFEL2. These isolates, based on taxonomical and $16 \mathrm{~S}$ rRNA sequence were belonged to Streptomyces sp. genus. This result confirms the abundance of Streptomyces in telluric ecosystems compared to the other genera of actinobacteria (Kitouni et al., 2005; Aouar et al., 2012). There are several reports indicating that rhizosphere is a very selective environment and microorganisms growing in this environment has low diversity. Therefore, they are ideal for use as biocontrol agents since the rhizosphere provides the front line defense for roots against attack by pathogen (Gracia et al., 2001; Maleki et al., 2010).

The three selected isolates were screened for different PGP traits such as phosphate solubilisation, siderophore production, IAA synthesis, ammonia (NH3), HCN and lower ethylene plant levels by synthetizing 1-aminocyclopropane-1carboxylate (ACC) deaminase activity and were found to be showing excellent PGP activities (Husen et al., 2011; Passari et al., 2015; Nguyen et al., 2016). Among some beneficial rhizosphere microorganisms, Streptomyces are mainly known to stimulate the growth of several annual crops. Streptomycete sp. have also received too much attention as biocontrol agents (Palaniyandi et al., 2011; Baz et al., 2012). In this study, we have detected that all the antagonistic actinomycetes produced ammonia. The amount of ammonia $(\mathrm{NH} 3)$ produced ranges between 477 to $631 \mathrm{mg} \cdot \mathrm{ml}^{-1}$. The ranges in our finding is higher than that reported by Passari et al. (2015), where the ammonia production ranged from 5.2 to $54 \mathrm{mg} \cdot \mathrm{ml}^{-1}$. The isolates, PFK4, PFBOT7 and PFEL2 produced different colours of aerial and substrate mycelium and were characterized by spiral spore chain morphology. These morphocultural characteristics and chain morphologies are typical of Streptomyces and related genera (Shirling and
Gotlllieb 1966). PFK4 and PFBOT7 showed good growth in the presence of $10 \% \mathrm{NaCl}$. They were also able to grow in the presence of crystal violet $(0.0001 \%)$; at $\mathrm{pH}$ of 4.5 to 9.5 , temperatures of $28{ }^{\circ} \mathrm{C}$ and $37{ }^{\circ} \mathrm{C}$, while isolate PFBOT7 was able to grow at $45^{\circ} \mathrm{C}$. The ability of actinomycetes to tolerate abiotic stress, including $\mathrm{pH}$, temperatures, salinity and other inhibitors had been reported (Aouar et al., 2012; Mouafo Tchinda et al., 2016). Additionally, biochemical characteristics showed that all the three active isolates were positive for the degradation of arbutin, easculin and starch, and negative for the degradation of xanhin. All the strains were positive for the degradation of maltose and sucrose except PFBOT7 and PEL1-2 respectively, and were positive for all the sources of nitrogen tested. Among the 287 isolates PFK4, PFBOT7 and PFEL2 were more representative and show growth promotion and biocontrol potential. Comparing with 16S rRNA gene sequence, the isolate PFK4 showed 99\% similarity with Streptomyces albulus (KJ778868.1); PFBOT7 showed 99\% with Streptomyces albus (DQ026669.1) and PFEL2 showed 98\% similarities with Streptomyces gandoceansis (KR303715.1). S. albulus are known for their ability to produce $\varepsilon$-polylysine, which exhibits antimicrobial activity against yeast, fungi and bacteria (Yoshida et al., 2003; Jianjun et al., 2012; Wu et al., 2015). S. albus has been isolated from diverse environments including sponges, sea sediments and insects and have been reported as biocontrol agents against fruit and vegetable pathogens (lan et al., 2014; Hanshew et al., 2014). Analysis of extracts derived from Streptomyces gandocaensis strain, which was isolated from marine sediment in Costa Rica, resulted in the discovery of an antibiotics cahuitamycins, new inhibitors of biofilm formation (Park et al., 2016). To the best of our knowledge, this is the first report where $S$. gandocaensis strain could be applied for the biological control. Further investigations are required to determine the mechanism involve and to confirm these findings.

\section{Materials and methods}

\section{Soil samples}

Soil samples were collected from the rhizosphere of healthy cocoyam plants in Boteva, Ekona, Ekona Lelu 1, Ekona Lelu 2 and Kumba in the South-West region, following the method described by Barakate et al. (2002). Five samples were taken from the rhizosphere of each locality with an auger (up to $15 \mathrm{~cm}$ deep) after removing $3 \mathrm{~cm}$ of the soil surface. Each sample was taken independently from the rhizosphere of five healthy cocoyam roots along the diagonal of the field. The soil samples were first mixed and after removing dirt, $500 \mathrm{~g}$ of soil were put in plastic polyethylene bags, tightly closed and kept at $4{ }^{\circ} \mathrm{C}$ during transportation to the Laboratory. The soil samples were then air-dried at room temperature for 10 days, sieved with a $0.8 \mathrm{~mm}$ mesh and stored at room temperature.

\section{Measurement of soil properties}

The properties of the soil were analysed according to the method of Lee and Hwang (2002). To determine the soil pH, 1g of air-dried soil was suspended in $10 \mathrm{ml}$ of distilled water and 
vigorously mixed to ensure uniformity. After being left to settle for $30 \mathrm{~min}$, the $\mathrm{pH}$ was measured in the supernatant of the soil suspension. The moisture content was measured by drying 10 $\mathrm{g}$ of air-dried soil sample overnight at $105^{\circ} \mathrm{C}$, to reach a constant weight. To determine organic-matter content, airdried soil samples were dried to constant weight at $105^{\circ} \mathrm{C}$ and then ashed at $450^{\circ} \mathrm{C}$ for $16 \mathrm{~h}$; organic-matter content was calculated as the average difference between dry and ash weights for each soil sample. The above soil properties were measured in 3 replicates.

\section{Isolation and enumeration}

The actinobacteria population in the rhizospheric soils of the cocoyam (Xanthosoma sagittifolium) plants was determined by serial dilution method. One gram of soil treated with $\mathrm{CaCO}_{3}$, was suspended in $9 \mathrm{ml}$ of sterile physiological water $(\mathrm{NaCl}, 9$ g. $\left.\mathrm{I}^{-1}\right)$. Inocula consisting of $0.1 \mathrm{ml}$ of dilutions $10^{-3}, 10^{-4}, 10^{-5}$ of soil sample suspension were spread on GLM culture media

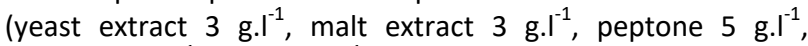
glucose 10 g..$^{-1}$, agar 20 g. $\left.\right|^{-1}$ ) and Bennett culture media (yeast extract $1 \mathrm{~g} . \mathrm{I}^{-1}$, beef extract $1 \mathrm{~g} . \mathrm{I}^{-1}$, casamino acids $2 \mathrm{~g}^{-1} \mathrm{I}^{-1}$, glucose

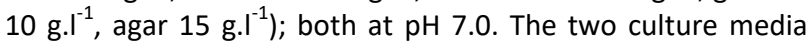
were supplemented with $40 \mu \mathrm{g} \cdot \mathrm{ml}^{-1}$ of nystatin and $10 \mu \mathrm{g} \cdot \mathrm{ml}^{-1}$ of nalidixic acid and incubated at $28{ }^{\circ} \mathrm{C}$ for four weeks (Kitouni et al., 2005). The treatments consisted of three dilutions for each of the 5 soils on GLM and Bennett media. The number of colony forming units (CFU.g ${ }^{-1}$ ) per gram of dried soil was calculated for each sample using plates that yielded 30-300 colonies. Distinct actinobacterial colonies were recognized according to morphological and macroscopic aspects by light microscopy (magnification $\times 100$ ). They were collected, subscultured on ISP2 agar medium for purification. The isolated colonies were kept in $20 \%$ glycerol at $-20{ }^{\circ} \mathrm{C}$ as stock culture.

\section{Antifungal and antibacterial activities}

According to their morphological and microscopic characteristics, the isolates were divided into 12 groups and screened for antagonism against five phytopathogenic fungi: $P$. myriotylum, Phytophthora erythroseptica (the causal agent of pink rot of potato), P. megakarya (causal agent of black pod disease in cocoa), Fusarium oxysporum and Colletotrichum gloeosporioides (causes anthracnose in yam) by dual culture in vitro assay (Soares et al., 2006). The antibacterial activity of the isolates was evaluated against two bacteria pathogens: Agrobacterium tumefaciens (causal agent of crown gall disease on Medicago sativa) and Streptomyces scabies EF-35 (causal agent of scab lesion on potato) using the agar diffusion method (Zhao et al., 2012).

\section{Extracellular enzymes production}

The proteolytic activity of actinobacterial isolates was determined on Skim Milk Agar medium. The isolates were streaked and incubated at $28{ }^{\circ} \mathrm{C}$ for 5 days (Sessitsch et al.,
2004). The chitinase activity of the isolates was assessed on colloidal chitin agar medium containing $2 \%$ colloidal chitin as described by Murthy and Bleakley (2012). Lipase production was evaluated on lipase agar medium according to (Smiberg and Krieg 1994). Cellulose and pectin degrading enzymes were detected using Yeast Extract Peptone Agar medium and Potato Dextrose Agar (PDA) medium supplement with $1 \%$ pectin, respectively, as described by $\mathrm{Hu}$ et al. (2008). All the treatments were replicated three times. The $\beta-1,3-$ glucanase test was done as per the protocols of Gopalakrishnan et al. (2014) on Tryptic Soy Broth (TSB), supplemented with $1 \%$ colloidal chitin (w/v).

\section{Plant growth promoting properties}

The selected antagonistic actinobacteria were evaluated for Plant Growth Promoting (PGP) traits including phosphate solubilisation, siderophore production, Indole Acetic Acid (IAA), ammonia $\left(\mathrm{NH}_{3}\right)$, ACC deaminase activity, hydrogen cyanide (HCN) production and nitrogen fixation. Phosphate solubilisation was evaluated by the method of Senthilkumar and Swarnalakshmi (2009). The siderophore production in the individual isolates was studied using the Chrome Azurol S (CAS) agar as described by Khamna et al. (2009). IAA was assayed, based on the colorimetric method described by Bano and Mussarat (2003). The antagonistic actinobacterial isolates were tested for the production of ammonia using the method described by Cappuccino and Sherman (2008). Actinobacteria strains were cultured in DF salts minimal agar medium containing $3 \mathrm{mM}$ filter-sterilized 1-aminocyclopropane-1carboxylic acid (ACC). Observation for growth and sporulation was made after 6 days of incubation at $28{ }^{\circ} \mathrm{C}$. The strains that were able to grow on this medium were considered ACC deaminase-positive (Penrose and Glick 2003). Hydrogen cyanide production was evaluated according to the method of Lorck (1948). Nitrogen fixation by antagonistic rhizospheric actinobacterial isolates was screened according to the method of Jensen (1942).

\section{Taxonomical characterization of isolates}

\section{Morphological characteristics}

All actinobacterial isolates were preliminarily identified using morphological characteristics after being cultured on various International Streptomyces Project (ISP) media including substrate and aerial hyphae on ISP2, ISP3, ISP4 and ISP5, melanoid or diffusible pigments production on ISP6 and ISP7 (Shirling and Gottlieb 1966), on Bennett and Glucoseasparagine. The production of melanin and diffusible pigments were determined on ISP6 and ISP7, respectively (Shirling and Gottlieb 1966). The colour of the colony was determined using the inter-society Colour Council-National Bureau of Standard (ISCC-NBS) colour chart. The morphology of spore-bearing hyphae and spore surface ornamentation of isolates were determined on ISP2 medium, using the cover-slip method and scan electron microscopy, as described by Williams et al. (1983) and Shimizu et al. (2002) respectively. 


\section{Physiological and biochemical characteristics}

The four active isolates (PEL1-2, PFK4, PFBOT7 and PFEL2) were examined for tolerance to salinity, the ability to grow under a range of $\mathrm{pH}$ and temperature, the ability to use to utilize different carbon or nitrogen sources. The isolates were streaked on ISP2 medium with various concentrations of $\mathrm{NaCl}$ ranging from 0 to $10 \%(\mathrm{w} / \mathrm{v})$, in order to evaluate their tolerance to $\mathrm{NaCl}$ using the method of Gordon and Barnett (1977). The plates were incubated at $28^{\circ} \mathrm{C}$ and the presence or absence of growth was recorded after 7 and 14 days. Tolerance to temperature and $\mathrm{pH}$ was tested on ISP2 as recommended by Williams et al. (1983). The assimilation of carbohydrates and nitrogen was studied using ISP9 medium containing different carbohydrates (1\%) as described by Shirling and Gottlieb (1966) and nitrogen $(0.1 \% \mathrm{w} / \mathrm{v})$ as described by Williams et al. (1983).

The antagonistic selected actinobacterial isolates were evaluated for several biochemical tests including nitrate reductase, catalase activity, oxidase test, gelatin liquefaction, urea hydrolysis, starch, arbutin and easculin hydrolysis (Shirling and Gottlieb 1966; Aouar et al., 2012). Treatments were replicated 3 times.

\section{Sequencing of the 16S rRNA gene and phylogenetic analysis}

Genomic DNA of antagonistic actinobacterial isolates was extracted by DNA extraction using Bacterial DNA Extraction Kit (Spin-column) following manufacturer's instructions. PCR amplification of $16 \mathrm{~S}$ rDNA gene were conducted using universal primers $F 8 / 20$ and $R / 1541$ (Monciardini et al., 2002). PCR conditions were: $3 \mathrm{~min}$ at $95^{\circ} \mathrm{C}$, followed by 35 cycles of 30 sec at $95^{\circ} \mathrm{C}, 30 \mathrm{sec}$ at $62^{\circ} \mathrm{C}$, and $90 \mathrm{sec}$ at $72^{\circ} \mathrm{C}$ and final extension at $72^{\circ} \mathrm{C}$ for $5 \mathrm{~min}$. PCR products were sequenced by first Base Laboratories Sdn. Bhd., Selangor, Malaysia. The obtained sequences were analysed using the BLAST (Basic Local Alignment Search Tool) program from Genbank database (http://www.ncbi.nlm.gov/BLAST). The resultant of 16 rRNA sequences were aligned by Clustal Omega and the tree was constructed with MEGA software version 7.0 (Kumar et al., 2016). The topologies of the neighbor-joining phylogenetic trees were evaluated in boostrap analyses of 1,000 replicates. The distances between sequences were calculated using the Kimura three-parameter (K3P) model (Kimura, 1981).

\section{Statistical analysis}

The data were analysed using graph pad prism software, version 6.01. The visual indication of data dispersion on bar and line graphs was achieved by means of standard errors of the mean. Data were subjected to the analysis of one-way analysis of variance ANOVA. All numeric differences in the data were considered significantly different at the probability level of $P<0.05$ according to Tukey test.

\section{Conclusion}

Among the 287 Streptomyces isolates from cocoyam rhizosphere in Mount Cameroon Region PFK4, PFBOT7 and
PFEL2 had high antagonistic effects against $P$. myriotylum, the most devastating disease of cocoyam. We used 16S rRNA gene sequence and isolates PFK4 and PFBOT7 showed 99\% similarity with with Streptomyces albulus and Streptomyces albus, respectively, and PFEL2 showed 98\% similarity with Streptomyces gandoceansis. Concurrent production of PGP substances coupled with broad spectrum of antifungal and antibacterial activities of these three strains suggest their potential use as promising biocontrol and PGP tools for the development of an alternative control method of cocoyam cultivations. In this study, we report S. gandocaensis strain for the first time as biological controller of Pythium myriotylum. Further investigations are required to confirm these findings.

\section{Acknowledgments}

The authors greatly acknowledge the "Fonds de Recherche du Quebec-Nature et Technologies (FRQNT)" for financing exchange visits between Cameroon and Canada (D.K.P.F visitor grant).

\section{References}

Adiobo A, Oumar O, Perneel M, Zok S, Holfte M (2007) Variation of Pythium-induced cocoyam root rot severity in response to type of soil. Soil Biol Biochem. 39: 2915-2925.

Aouar L, Lerat S, Ouffroukh A, Boulahrouf A, Beaulieu C (2012) Taxonomic identification of rhizospheric actinobacteria isolated from algerian semi-arid soil exhibiting antagonistic activities against plant fungal pathogens. Can J Plant Pathol. 34: 165-176.

Bano N, Musarrat J (2003) Characterization of a new Pseudomonas aeruginosa strain $\mathrm{NJ}-15$ as a potential biocontrol agent. Curr Microbiol. 46: 324-348.

Barakate M, Ouhdouch Y, Oufdou K, Beaulieu C (2002). Characterization of rhizospheric soil streptomycetes from Moroccan habitats and their antimicrobial activities. World J Microb Biot. 17: 49-54.

Baz M, Lahbabi D, Samri S, Val F, Hamelin G, Madore I, Bouarab K, Beaulieu C, Ennaji M, Barakate M (2012) Control of potato soft rot caused by Pectobacterium carotovorum and Pectobacterium atrosepticum by Moroccan actinobacteria isolates. World J Microb Biot. 28: 303-311.

Boudjeko $\mathrm{T}$, Andème-Onzighi $\mathrm{C}$, Vicré $\mathrm{M}$, Omokolo-Ndoumou $D$, Driouich A (2006) Loss of pectin is an early event during infection of cocoyam roots by Pythium myriotylum. Planta. 223: 271-282.

Boudjeko T, Mouafo Tchinda RA, Zitouni M, Tchatchou Nana JAV, Lerat S, Beaulieu C (2017) Streptomyces cameroonensis sp. nov., a geldanamycin producer that promotes Theobroma cacao growth. Microbes Environ. 32 (1): 24-31.

Boudjeko T, Omokolo NA, Driouich A, Balangé AP (2005) Peroxydase and pectin methylesterase activities in cocoyam (Xanthosoma sagittifolium L. Schott) root upon Pythium myriotylum inoculation. J Phytopathol. 153: 409-416.

Cappuccino JC, Sherman N (2008) Microbiology: A Laboratory Manual. Pearson Benjamin Cummings. 
Doumbou CL, Salove MKH, Crawford DL, Beaulieu C (2001) Actinomycetes, promising tools to control plant diseases and to promote plant growth. Phytoprotection. 82: 85-102.

El-Tarabily KA, Hardy GESJ, Sivasithamparam K (2010) Performance of three endophytic actinomycetes in relation to plant growth promotion and biological control of Pythium aphanidermatum, a pathogen of cucumber under commercial field production conditions in the United Arab Emirates. Eur J Plant Pathol. 128: 527-539.

FAOSTAT (2014). Food and agriculture organization of the United Nations. Rome Italy, www.fao.org/3/a-i3590e.Pdf.

Gopalakrishnan S, Vadlamudi S, Bandikinda P, Sathya A, Vijayabharathi R, Rupela O, Kudapa H, Katta K, Varshney RK (2014) Evaluation of Streptomyces strains isolated from herbal vermicompost for their plant growth-promotion traits in rice. Microbiol Res. 169: 40-48.

Gordon RE, Barnett DA (1977) Resistance to rifampicin a lysozyme of strains of some species of Mycobacterium and Nocardia as taxonomic tool. Int J Syst Bacterio. 27: 176-178.

Gracia IE, Hynes RK, Nelson LM (2001) Cytokinin production by plant growth promoting rhizobacteria and selected mutants. Can J Microbiol. 47: 404- 411.

Hanshew AS, McDonald BR, Díaz-Díaz C, Djieto-Lordon C, Blatrix R, Currie CR (2014) Characterization of actinobacteria associated with three ant-plant mutualisms. Microbial Ecol. 69(1): 192-203.

Hu XF, Ying FX, He YB, Gao YY, Chen HM, Chen JS (2008) Characterization of Pectobacterium carotovorum sub sp. Carotovorum causing soft-rot disease on Penellia ternate in China. Eur J Plant Pathol. 120(3): 305-310.

Husen E, Wahyuli AT, Suwanto A, Giyanto G (2011) Growth enhancement and disease reduction of soybean by 1 aminocyclopropane-1-carboxylate deaminase-producing Pseudomonas. Am J App Sci. 8: 1073-1080.

Ian E, Malko DB, Sekurova ON, Bredholt $H$, Rückert C, Borisova ME, Albersmeier A, Kalinowski J, Gelfand MS, Zot SB (2014) Genomics of sponge-associated streptomyces spp. slosely related to Streptomyces albus J1074: insights into marine adaptation and secondary metabolite biosynthesis potential. Plos One. 9(5): e96719.

Jensen HL (1942) Nitrogen fixation in leguminous plants. General characters of root-nodule bacteria isolated from species of Medicago and Trifolium in Australia. Proc Lin Soc New S Wales. 67: 98-108.

Jianjun L, Hui L, Peng G, Meiying H (2012) Isolation and identification of actinomyces strain MY-4 and its antagonistic activity against pathogenic fungi of fruits and vegetables. J Fruit Sci. 29: 644-649.

Khamna S, Yokata A, Lumyong S (2009) Actinomycetes isolated from medicinal plant rhizosphere soils: diversity and screening of antifungal compounds, indole-3-acetic acid and siderophore production. World J Microb Biot. 25: 649-655.

Kimura M (1981) Estimation of evolutionary distances between homologous nucleotide sequences. Proc Nat Acad Sci USA. 78: 454-458.

Kitouni M, Boudemagh A, Oulmi L, Reghoua S, Boughachiche F, Zerizer $H$, Hamdiken $H$, Couble A, Mouniee D, Boulahrouf $A$, Boiron P (2005) Isolation of actinomycetes producing bioactives substances from water, soil and tree bark samples of the North-east of Algeria. J Mycol Med. 15: 45-51.

Kumar S, Stecher G, Tamura K (2016) MEGA 7: Molecular Genetics Analysis Version 7.0 for bigger Datasets. Mol Biol Evol. 33: 1870-1874.

Lee JY, Hwang BK (2002) Diversity of antifungal actinomycetes in various vegetative soils of Korea. NRC Research Press. Can J Microbio. 48: 407-417.

Lorck H (1942) Production of hydrocyanic acid by bacteria. Physiol Plantarum. 1: 142-146.

Lugtengberg B, Kimilova F (2009). Plant growth-promoting rhizobacteria. Annu Rev Microbiol. 63: 541-556.

Ma Z, Hoang-Hua GK, Ongena M, Hofte M (2016) Role of phenazines and cyclic lipopeptides produced by pseudomonas sp. CMR12a in induced systemic resistance on rice and bean. Env Microbiol Rep. 8(5): 896-904.

Maleki M, Mostafee S, Mohammad L, Farzenah M (2010) Characterization of Pseudomonas fluorescens strains CV-6 isolated from cucumber rhizosphere in varamin as a potential biocontrol agent. Aust J Crop Sci. 4(9): 676-683.

Mbarga JB, Hoopen GMT, Kuaté J, Adiobo A, Ngonkeu MEL, Ambang Z, Akoa A, Tondje PR, Begoude BAD (2012) Trichoderma asperellum: A potential biocontrol agent for Pythium myriotylum causal agent of cocoyam (Xanthosoma sagittifolium) root rot disease in Cameroon. Crop Prot. 36: 18-22.

Monciardini P, Sosio M, Cavaletti L, Chiocchini C, Donadio S (2002) New PCR primers for the selective amplification of $16 S$ rDNA from different groups of actinomycetes. FEMS Microbiol Ecol. 42: 419-429.

Mouafo Tchinda RA, Boudjeko T, Simao-Beaunoir AM, Lerat S, Tsala E, Monga E, Beaulieu C (2016) Morphological, physiological and taxonomic characterization of actinobacterial isolates living as endophytes of cacao pods and cacao seeds. Microbes Environ. 31(1): 56-62.

Murthy N, Bleakley B (2012) Simplified method of preparing colloidal chitin used for screening of chitinase-producing microorganisms. Int J Microbiol. 10: 2-8.

Nguyen TT, Ho VH, Nguyen HT (2016) Screening of strong 1aminocyclopropane-1-carboxylate deaminase producing bacteria for improving the salinity tolerance in Cowpea. Applied Microbiol. 2: 1-6.

Nyochembeng LM, Beyl CA, Pacumbaba RP (2007) Peroxidase activity, isozyme patterns and electrolyte leakage in roots of cocoyam infected with Pythium myriotylum. J Phytopathol. 155: 454-461.

Nzietchueng S (1983) La pourriture racinaire du macabo (Xanthosoma sagittifolium) au Cameroun: ISymptomatologie et étiologie de la maladie. Agron Trop. 38: 321-324.

Palaniyandi SA, Yang SH, Cheng JH, Meng L, Suh JW (2011) Biological control of anthracnose (Colletotrichum gloeosporioides) in yam by Streptomyces sp. MJM5763. J Applied Microbiol. 111: 443-455.

Palaniyandi SA, Yang SH, Damodharan K, Suh JH (2013) Genetic and functional characterization of culturable plant-beneficial actinobacteria associated with yam rhizosphere. J Basic Microb. 985-995. 
Park SR, Tripathi A, Wu J, Schultz PJ, Yim I, McQuade TJ, Yu F, Arevang CJ, Mensah AY, Tamayo-Castillo G, Xi C, Sherman DH (2016) Discovery of cahuitamycins as biofilm inhibitors derived from a convergent biosynthetic pathway. Nat Comm. 7: 10710.

Passari AK, Mishra VK, Gupta VK, Yadav MK, Saikia R, Singh BP (2015) In vitro and in vivo plant growth promoting activity and DNA finger printing of antagonistic endophytes actinomycetes associates with medicinal plants. Plos One J. 1-18.

Penrose DM, Glick BR (2003) Methods of isolating and characterizing ACC deaminase containing plant growth promoting rhizobacteria. Physiol Plantarum. 118: 10-15.

Perneel M, Tambong JT, Adiobo A, Floren C, Saborìo F, Lévesque A, Höfte $M$ (2006) Intraspecific variability of Phytium myriotylum isolated from cocoyam and other host crops. Mycol Res. 583-593.

Perneel M, Heyrman J, Adiobo A, De Maeyer K, Raaijmakers JM, De Vos P, Höfte M (2007) Characterization of CMR5c and CMR12a, novel fluorescent Pseudomonas strains from the cocoyam rhizosphere with biocontrol activity. J Applied Microbiol. 103: 1007-1020.

Reyes G, Nyman M, Rönnberg-Wästljung AC (2005) Agronomic performance of three cocoyam (Xanthosoma violaceum Schott) genotypes grown in Nicaragua. Euphytica. 142: 265272.

Sadeghi A, Koobaz P, Azimi H, Karimi E, Akbari AR (2017) Plant growth promotion and suppression of Phytophthora drechsleri damping-off in cucumber by cellulase-producing Streptomyces. BioControl. DOI 10.1007/s10526-017-9838-4.

Schrey SD, Tarkka MT (2008) Friends and Foes: streptomycetes as modulators of plant disease and symbiosis. A Van Leeuw J Microb. 94: 11-19.

Sefa-Dedeh S, Agyir-Sackey EK (2004) Chemical composition and the effect of processing on oxalate content of cocoyam Xanthosoma sagittifolium and Colecasia esculenta cormels. Food Chem. 85: 479-485.

Senthilkumar M, Swarnalakshmi K (2009) Biocontrol potential of soybean endophytes against charcoal rot fungus, Rhizoctonia bataticola. Curr Microbiol. 58: 288-293.

Sessitsch A, Reiter B, Berg G, (2004) Endophytic bacterial communities of field-grown potato plants and their plantgrowth-promoting and antagonistic abilities. Can J Microbio. 50(4): 239-249.
Shimizu M, Nakagawa $Y$, Sato $Y$, Funumai $Y$, Igoroshi $Y$, Onaka H, Yoshida R, Kunoh H (2002) Studies on endophytic actinomycetes I Streptomyces sp. isolated from Rododendron and its antifungal activity. J Gen Plant Pathol. 66:360-366.

Shirling EB, Gottlieb DD (1966) Methods for characterization of streptomyces. Int J Syst Bacteriol. 13: 313-340.

Smiberg RM, Krieg NR (1994) Phenotypic characterization in methods of general and molecular bacteriology. Am Soc Microbiol. 611-651.

Soares FCA, Soussa SDA, Garrido SDM, Perez OJ, Almeida DSM (2006) Soils streptomyces with in vitro activity against the yams pathogens Curvularia eragrostides and Colletotrichum gloleosporiodes. Braz J Microbiol. 37: 456 - 461.

Williams ST, Goodfellow M, Alderson G, Wellington EMH, Sneath PHA, Sackin HJ (1983) Numerical classification of Streptomyces and related genera. J Gen Microbiol. 129: 1743-1813.

Wu Y, Yuan JEY, Raza W, Shen Q, Huang Q (2015) Effects of volatile organic compounds from Streptomyces albulus NJZJSA2 on growth of two fungal pathogens. J Basic Microb. 55: 1104-1117.

Yang S, Huang Y, Wang C, Zhao P, Zhang W (2014) Isolation, identification of TJ430 strain and characterization of its antifungal metabolite. Acta Microbiol Sin. 54(6): 624-634.

Yoshida T, Nagasawa T (2003) Epsilon-poly-L-lysine: microbial production, biodegradation and application potential. Appl Microbiol Biot. 62: 21-26.

Zhao J, Xue QH, Shen GH, Xue L, Duan JL, Wang DS (2012) Evaluation of Streptomyces spp for biocontrol of gummy stem blight (Didymella bryoniae) and plant growth promotion of Cucumis melo L. Biocontrol Sci Techn. 22: 2337. 